\title{
JUDGING SELECTION: APPOINTING CANADIAN JUDGES
}

\section{Peter McCormick*}

Since the 1970s, the appointment of trial judges in Canada has generally involved an arms-length committee of professionals, although the structure of these committees and their role in the process has varied from province to province, as well as evolving over time. Yet these "new" structures and "new" processes did not prevent a major judicial appointment scandal in the province of Quebec in 2010, culminating in the formation of the Bastarache Committee to recommend changes. This paper summarizes the forty-year history of Canadian judicial appointment committees, identifies the major challenges that face those committees, and suggests the basic values toward which reforms to the appointment process might be directed.

Depuis les années 1970, la nomination des juges de première instance au Canada a généralement mis à contribution un comité de professionnels indépendants, bien que la structure de ce comité et son rôle dans le processus de nomination aient varié d'une province à l'autre et évolué avec le temps. Ces "nouvelles» structures et "nouveaux» processus n'ont certes pas empêché l'éclatement du scandale sur la nomination des juges au Québec en 2010. Ce scandale a donné lieu à la formation de la Commission Bastarache qui avait notamment le mandat de recommander des changements. La présent document résume les quarante ans d'histoire des comités canadiens de nomination des juges, recense les principaux défis que ces comités doivent relever, et propose les valeurs fondamentales qui devraient inspirer les réformes du processus de nomination.

"One should never underestimate the power of appointment." Donald J. Savoie, Power: Where is it?

\section{INTRODUCTION}

Judges, and the ways that judges are selected, have recently been in the news, and not in a good way. In the summer of 2010, a former Quebec Minister of Justice gave sworn testimony before a provincial commission of inquiry alleging that improper pressures and procedures had directed the selection of at least three judges of the Cour du Québec, and possibly the designation of an associate chief judge as well. To be sure, allegations are not necessarily facts, and much of the

University of Lethbridge

(2012) 30 Windsor Y B Access Just 
controversy ultimately involved "he said, she said" arguments between the premier and the former minister. In the end, the report of the Bastarache Committee exonerated then Premier Charest and his cabinet of most of the more lurid allegations, but it was critical of the procedures and recommended major changes. The events cast an unusual and unfortunate shadow over the way Canadian trial judges are selected.

It was not supposed to be like this. For forty years, various Canadian jurisdictions have been evolving structures and procedures for an independent and professional evaluation of judicial candidates, moving away from unfettered ministerial discretion -- the practice that Evans sardonically labelled "The Power of One." ${ }^{2}$ The reformist trajectory began with Ontario's Judicial Council in 1968, and the most recent institutional innovation was Alberta's Provincial Court Nominating Committee in 1999. The thirty years in between are not a story of straightforward policy diffusion, with a new idea in one province copied and refined by a string of other provinces, but rather something that has moved through several distinct phases and even now embraces several distinctly different models. But what all have had in common is the ostensible purpose of constraining executive choice, of providing an answer to the question "why was that person appointed?" that involves something more than "the Minister decided".

The story of this evolution is a complicated one that has not been well chronicled. The best short summary is found in Friedland's slightly dated 1995 study of judicial independence ${ }^{3}$ and in an even more dated study of judicial councils. ${ }^{4}$ Morton's ${ }^{5}$ is the most recent addition to the literature, but even though this is now the "go to" source on the subject for foreign researchers, it is surprisingly inaccurate in many respects. ${ }^{6}$ For example: he says that in several provinces judicial appointment is entirely at the discretion of the minister, and that in several other provinces the minister refers a single name to a committee for possible veto; neither statement has been true of any province since 1995. His further suggestion that the Ministers in Ontario, Alberta and British Columbia receive a single name which they can (but rarely do) reject is wrong on all three counts. I wish to correct the record on these matters.

1 Michel Bastarache, Commission d'enquête sur le processus de nomination des juges de la Court du Québec, de courts municpales, et des membres du Tribunal administratif du Québec: rapport (Les Publications du Québec, 2011)

2 Jim Evans, "The Power of One -- Judicial Appointments in New Zealand" (Paper delivered at the Conference on Judicial Reform: Function, Appointment and Structure, University of Cambridge, 4 October 2003) <http://www.law.cam.ac.uk/faculty-resources/conference-papers/17>.

3 Martin L Friedland, A Place Apart: Judicial Independence and Accountability in Canada (Ottawa: Canadian Judicial Council, 1995).

4 Peter McCormick, "Judicial Councils for Provincial Judges in Canada" (1986) 6 Windsor YB Access Just 160.

5 FL Morton, "Judicial Appointments in Post-Charter Canada: A System in Transition" in Kate Malleson \& Peter H Russell, eds, Appointing Judges in an Age of Judicial Power: Critical Perspectives from Around the World (Toronto: University of Toronto Press, 2006).

6 Julie Chalmers, "Matters of Judicial Appointments, Conduct and Removals in Commonwealth Jurisdictions - Research Findings"(2008) Government of Scotland Research Paper 08, online: Government of Scotland <www.scotland.gov.uk/Publications/2008/01/04135549/0>. 
Table 1: Judicial Selection Committees in Canada

\begin{tabular}{|l|l|l|c|}
\hline Province & Structure & Abbrev. & Year \\
\hline Ontario & Judicial Council & ON JC & 1968 \\
\hline $\begin{array}{l}\text { British } \\
\text { Columbia }\end{array}$ & Judicial Council & BC JC & 1974 \\
\hline Alberta & Judicial Council & AB JC & 1975 \\
\hline Newfoundland & Judicial Council & NF JC & 1975 \\
\hline Saskatchewan & Judicial Council & SK JC & 1978 \\
\hline Quebec & Selection committee $($ ad hoc $)$ & & 1979 \\
\hline $\begin{array}{l}\text { New } \\
\text { Brunswick }\end{array}$ & Judicial Council NB JC & 1985 \\
\hline Canada & Judicial Advisory Committees & JAC & 1988 \\
\hline $\begin{array}{l}\text { New } \\
\text { Brunswick }\end{array}$ & $\begin{array}{l}\text { Provincial Judicial Appointment Review } \\
\text { advisors }\end{array}$ & NB PJAR & 1988 \\
\hline Ontario & Judicial Appointments Advisory Committee & ON JAAC & 1989 \\
\hline Nova Scotia & $\begin{array}{l}\text { Advisory Committee on Provincial Judicial } \\
\text { Appointments }\end{array}$ & NS ACPJA & 1989 \\
\hline Manitoba & Judicial Nominating Committee $($ ad hoc $)$ & MN JNC & 1990 \\
\hline P.E.I. & $\begin{array}{l}\text { Judicial Appointments Advisory Committee } \\
(\text { ad hoc })\end{array}$ & PEI JAAC & 1995 \\
\hline Alberta & Provincial Court Nominating Committee & AB PCNC & 1999 \\
\hline
\end{tabular}

My purpose is to describe how Canadian trial judges are appointed today, to link this to a developmental process that began in 1968, and to show why this has failed to prevent practices such as those alleged to have happened in Quebec. Table 1 is a general introduction to this history, listing all the bodies involved in considering judicial appointments over the last four decades. The list is longer than might be expected, reflecting the fact that some of these bodies (such as the Judicial Councils of Ontario and New Brunswick) are no longer involved, and some provinces (such as Alberta) now use more than one committee in the process. Also, the dates reflect not the first establishment of the body in question, but rather when they became part of the appointment process ${ }^{7}$.

\section{THE JUDICIAL COUNCIL PERIOD 1970-1985}

The 1970s was a decade of progressive policies and aggressive government activism, and among the reforms tackled by all the provinces in quick succession was a major overhaul of the provincial court system, including the replacement of magistrates' courts with fully professionalized Provincial Courts, supported by

7 The "historic" information on appointment procedures in the 1980s is taken from my earlier WYAJ article, which drew on statutory information and interviews with judicial council members in several provinces and with some provincial attorneys-general. McCormick, supra note 4. Updating that information to describe current provincial judicial appointment structures and processes has proved to be a surprising challenge, because reporting practices vary remarkably from one province to another. For a more complete and extended statement of the sources from which the information was drawn, please see my (much longer) expert report for the Inquiry Commission into the appointment process for judges to the Court of Quebec, municipal courts and the Tribunal administratif du Québec [Bastarache Commission] online: Inquiry Commission into the Appointment Process for Judges <www.cepnj.gouv.qc.ca/english.html>. 
institutional innovations that enhanced their formal judicial independence. These were the reforms already in place at the time of the Valente case, when the Supreme Court found that these measures satisfied the Charter standards of judicial independence, effectively reading them back into the constitution. ${ }^{9}$

One of these innovations was the Judicial Council for Provincial Court Judges, first established in Ontario in 1968 and spreading to every province except Prince Edward Island by 1985 . $^{10}$ The major purpose of these councils was to anchor the judicial independence of the new provincial courts by providing a mechanism for dealing with complaints against judges that did not raise the spectre of governmental interference. Although this basic idea spread quickly, the details did not -- the various councils looked quite different, and they fitted into the complaint/discipline process in quite different ways. More important for the immediate purpose, a number of the Councils were assigned other functions as well, one being a role in judicial appointments by providing an independent professional valuation of potential judges.

Table 2: Judicial Councils as Nomination Committees

\begin{tabular}{|l|l|l|l|l|l|l|}
\hline & Ontario & B.C. & Alberta & Nfld. & Sask. & N.B. \\
\hline Began: & 1968 & 1974 & 1975 & 1975 & 1978 & 1985 \\
\hline CJPC & Yes & Yes* & Yes & Yes* & Yes & Yes* \\
\hline CJCA & Yes* & & Yes & & Yes* & Yes \\
\hline CJQB & Yes & & Yes & & Yes & \\
\hline ProvLawSoc & Yes & Yes & Yes & Yes & Yes & Yes \\
\hline CBA (prov) & & Yes & & & & \\
\hline Other prov j & Yes (2) & Yes (2) & & Yes & Yes (2) & \\
\hline Lay/public & Yes (2) & Yes (2) & Yes (2) & Yes (2) & Yes (2) & Yes (2) \\
\hline Other lawyer & & Yes (1) & & & & \\
\hline Other & & Yes (1) & & & & \\
\hline Size & 8 & 9 & 6 & 5 & 8 & 5 \\
\hline Ended: & 1995 & & & & & 1988 \\
\hline
\end{tabular}

$*$ = chair of Council

Table 2 shows the basic similarity of the Councils that had a role in appointments. They all included the Chief Judge of Provincial Court, often as chair; and most included the Chief Justices of one or both of the provincial superior courts, this accounting for most of the times that the CJPC did not chair. The current standard structure has two provincial superior courts -- a trial court and a court of appeal -- in each province, hence two s.96 Chief Justices; but forty years ago every province other than Quebec had a second tier of provincial superior trial courts -- a "District Court" or a "County Court" -- and therefore an additional s.96 Chief Justice, some of whom served on the relevant council/committee. Alberta is the odd province out in this respect, chaired by a lay member for the whole period. The provincial law society is represented in every

$8 \quad R v$ Valente [1985] 2 SCR 673

9 Peter McCormick, "New Questions about an Old Concept: The Supreme Court of Canada's

10 Judicial Independence Decisions" (2004) 37 Canadian Journal of Political Science 839. Supra note 4. 
province, the Canadian Bar Association (provincial branch) in only one. All include lay representation -- intriguingly, all include the same number of lay representatives, namely two -- in the form of order-in-council appointments. Basically, they are all dominated by their judicial members; judges make up about $50 \%$ of the six-council total, lay members $30 \%$ and lawyers $20 \%$, and all but one of the councils are chaired by judges. This is an obvious consequence of the complaint/discipline function and its major implications for judicial independence.

But not all councils were engaged in the judicial selection process in the same way. Ontario's was the prototype council, receiving the name of a proposed appointment from the minister, assessing that person's qualifications and reporting their conclusions to the minister (I will refer to this as a "veto council.") Saskatchewan followed the same practice, except that it did not, and the Ontario Council always did, interview the nominee. But British Columbia followed a different plan; aspirants for appointment to the provincial bench made a formal application, all applicants were screened and interviewed by the Judicial Council, and the minister filled vacancies by appointing from the pool of approved applicants. When Alberta and Newfoundland established their councils in 1975, both used the Ontario legislation as their model and both intended to establish veto councils, but in practice they followed B.C. as a screening council, as did New Brunswick (briefly) a decade later.

For these first fifteen years, then: six provinces used judicial councils to screen judicial appointments, two as veto councils and four as screening councils; and three provinces (Nova Scotia, Manitoba and Prince Edward Island) made no changes at all to the traditional procedure for appointing provincial judges, leaving it to the opaque discretion of provincial ministers. This leaves Quebec as an outlier, establishing a procedure for screening appointments that did not use the Judicial Council (although Quebec established one of these in 1978). Instead, Quebec provided for an ad hoc selection committee, consisting of a judge, a lawyer and a layperson, to be established whenever a vacancy occurred to review applications for that position and to recommend qualified candidates to the minister. $^{12}$ This represents a triple novelty: first, a single purpose judicial screening committee in place of the multi-purpose judicial council; second, an ad hoc committee rather than a standing committee; and thirdly, a committee to deal with a specific vacancy (a "reactive" committee) rather than one to generate a pool of qualified candidates in anticipation of a possible future vacancy (an "anticipatory" committee). As the next section will show, all three of these ideas had legs.

\section{THE NOMINATING COMMITTEE PERIOD 1985-2000}

If the dominant trend of the first fifteen years was the use of judicial councils, the trend for the next fifteen was the adoption of single-purpose nominating committees; by the end of the century, most provinces had gone this route, two of them (Ontario and New Brunswick) after having tried judicial councils for the purpose. Table 3 provides the dates for this progression, and the committee

11 Ibid.

12 Louis Vaillancourt, “Je veux devenir juge: à qui m'addresser?” (1994) 25 RGD 269. 
structures that were established in each of the provinces (including that of Quebec, the only province to use a single-purpose committee in the first fifteen years).

Table 3: Provincial Appointment Advisory Committees

\begin{tabular}{|l|l|l|l|l|l|l|l|}
\hline Province & Quebec & Manitoba & P. E. I. & N.B. & Ontario & N. S. & Alberta \\
\hline Established & 1979 & 1990 & 1995 & 1988 & 1989 & 1989 & 1999 \\
\hline CJPC & & Yes* & Yes* & & & & \\
\hline CJCA & & & & Yes & & & \\
\hline CJQB & & & & Yes & & & \\
\hline ProvLawSoc & Yes & Yes & Yes & Yes & Yes & Yes (2) & Yes \\
\hline CBA (prov) & & Yes & Yes & Yes & Yes & & Yes \\
\hline Other prov j & Yes & Yes & & Yes & Yes (2) & Yes (2) & Yes \\
\hline $\begin{array}{l}\text { Lay/public } \\
\text { oic }\end{array}$ & Yes & Yes (3) & $\begin{array}{l}\text { Yes } \\
(2)\end{array}$ & Yes (2) & Yes (7) & Yes (4)\# & Yes (4) \\
\hline Other lawyer & & & & Yes (2) & Yes (1) & & Yes (4) \\
\hline $\begin{array}{l}\text { Other } \\
\text { Size }\end{array}$ & 3 & 7 & 5 & 9 & $\begin{array}{l}\text { Yes } \\
(1) @\end{array}$ & & \\
\hline AH/standing & Ad Hoc & Ad Hoc & $\begin{array}{l}\text { Ad } \\
\text { Hoc }\end{array}$ & Standing & Standing & Standing & Standing \\
& & & & & & \\
\hline
\end{tabular}

* = chair of committee

\# = four "other" members, at least two lay

$@=$ one member of Judicial Council (in practice, always a judge)

As the bottom row suggests, this is not really a single story unfolding over a fifteen year period, but rather two different stories. The first is the story of the Quebec model -- the ad hoc reactive style of nominating committee set up in that province in 1979 , largely imitated by Manitoba in $1990^{13}$ and then by P.E.I. in 1995. Both of these committees are rather larger than Quebec's logical minimum of three persons, and both include the Chief Judge of Provincial Court as the ex officio chair. (In Quebec, the single judicial member is recommended by the Chief Judge, and the chair is named by the Minister.) The additional members include another judge for Manitoba, another lawyer for both Manitoba and P.E.I., and additional lay members for both provinces to bring them up to just under a majority of the committee. Like Quebec, these committees are established in response to a specific vacancy, they consider applications targeted at that position, and they identify the applicants who are qualified for appointment, with the final selection being made by the minister. In Manitoba alone, it is stipulated that the submitted list must include at least three names, but not more than six.

The second story is about a new model emerging more or less simultaneously in Nova Scotia and Ontario. This involves a separation of the committee from the office of Chief Judge and a strong lay representation on a large standing committee -- Nova Scotia with a total of eight members including four lay members, and Ontario initially with eight gradually expanded to thirteen including seven lay members, one of whom chairs the committee. The most recent addition to this list is the Provincial Court Nomination Committee in Alberta, which includes one judge (the Chief Judge or designate), two lawyers (the President of 
the Law Society of Alberta and the President of the Alberta Branch of the Canadian Bar Association), and eight other members named by the minister -- at the moment, these eight include four lawyers and four lay members, although earlier in the decade it was three lawyers and five lay members. The Alberta chair is also selected by the minister, and is currently one of the lawyer members. An unusual feature is that unlike Ontario, where the JAAC displaced the Ontario Judicial Council from the appointment process, Alberta's PCNC supplements the role of the Alberta Judicial Council -- indeed, both interview candidates, making Alberta the only province with such a double hurdle. ${ }^{14}$

The impression of policy diffusion or emulation, however, is undermined by the different ways that different committees are involved in the appointment process. The Nova Scotia ACPJA is an anticipatory committee, receiving applications on an ongoing basis to generate a pool of qualified applicants from which the minister may appoint when necessary. The Ontario JAAC is a reactive committee, advertising actual vacancies to solicit targeted applications and ultimately presenting a short-list to the minister. This makes the Ontario committee a unique combination of a standing reactive committee; it is also one of only two committees in the country whose final product is a short list. The Alberta PCNC started as a reactive committee (drawing from the pool created by the Judicial Council to respond to a specific vacancy), but has since become an anticipatory committee generating its own pool of qualified candidates from those approved by the Judicial Council.

Quebec was the outlier province in the first fifteen years; New Brunswick is the outlier for the second. I have referred to New Brunswick's body as a committee (and the single-sentence comment on the Provincial Court website also uses this term), but it does not appear that the group ever meets. Instead, this is a group of advisors who receive the files of applicants and independently submit their separate evaluations to the minister, who uses this input to generate a list of qualified candidates. When a vacancy occurs, the minister can draw on this list (although he is not restricted to it) for a nominee who is interviewed by a special ad hoc committee (consisting of the current or a past Chief Justice, the current or a past Chief Judge, and one of the lay advisors) which reviews this nomination. ${ }^{15}$

The diversity of the first fifteen years continues: now the relevant bodies include four judicial councils (all anticipatory), three ad hoc reactive committees, one standing reactive committee, two standing anticipatory committees, and one dispersed group of advisors. A mild (six provinces out of ten) preference for councils has been replaced by an equally mild preference for single-purpose committees, although these are not all of a kind; and the earlier division between veto councils and anticipatory councils has now been replaced by a division between anticipatory committees and reactive committees. There is still no sign of policy convergence.

14 Peter Bowal, "Help Wanted: Judges”, LawNow (June/July 2006) online: Legal Studies Program, University of Alberta <https://dspace.ucalgary.ca/bitstream/1880/47966/1/

Bowal_Help2006_LawNow.pdf >.

15 Roger Bilodeau \& Denis Roy, "Le processus de consultation et d'évaluation entourant les nominations au cour provinciale du nouveau brunswick" (2000) 38 Alta L Rev 867; Martin L. Friedland, A Place Apart: Judicial Independence and Accountability in Canada (Ottawa: Canadian Judicial Council, 1995). 


\section{CODA: FEDERAL JUDICIAL SELECTION}

Since 1988, the federal government has used Judicial Advisory Committees for making appointments to the provincial superior courts and the federal courts (trial and appeal). The committees initially consisted of five members -- a nominee of the relevant provincial or territorial law society, a nominee of the relevant branch of the Canadian Bar Association, a judge nominated by the Chief Justice of the relevant province or territory, a person nominated by the relevant provincial attorney-general or territorial minister of justice, and one person appointed by the federal Minister of Justice to represent the general public. (For the first four, a list of names for each position is submitted to the minister, who chooses which one will serve.) This was adjusted in 1994, increasing the number of persons appointed by the Minister of Justice from one to three, two of whom are lay people and one is a lawyer. ${ }^{16}$ More recently, the Harper government announced changes to the membership of the committee in November 2006, adding a new position in the form of a person nominated by the relevant law enforcement community; at the same time, the judicial member of the committee was made a non-voting member except in case of a tie vote. Members are appointed to the committees for threeyear terms and can be reappointed once.

The committee receives credential-cleared applications from the Office of the Commissioner for Federal Judicial Affairs, and undertakes "extensive consultation" with the appropriate legal and non-legal communities. The committee discusses each candidate and decides whether or not they can be recommended for appointment. Initially, they were to divide applicants into "Qualified" and "Not Qualified" categories. In 1991, this was changed to the three categories of "Highly Recommended" and "Recommended" and "Unable to Recommend"; and in 2006, this was changed again to the two categories of "Recommended" and "Unable to Recommend".

The committees' assessments remain valid for two years (before 1999, it was three years), and during this period they constitute a pool from which the minister may select. No formal mandate requires the minister only to appoint from the committee's "recommended" list; this practice rests on a "personal undertaking" by the then Minister of Justice in 1994, an undertaking has been honoured since but never put on a formal basis. Even should the minister select a name from the list, however, he or she conducts separate extensive consultations with the judiciary, the legal community, the relevant provincial or territorial minister, and members of the general public.

Several features of the federal process should be noted. The first is the lack of a formal statutory basis and a resulting extensive ministerial discretion, such that the committee's membership can be altered, or their terms changed, or their mandate adjusted (for example, to include or exclude the review of applications from sitting judges) without publicity or debate. For another, the minister has an extraordinary degree of control over the actual membership of the committee, unlike the ex officio or independent designation procedures of most provinces. For yet another, because the committee is anticipatory rather than reactive, it cannot say "this candidate is the best fit for this position" but can only say more abstractly

16 Andre S Millar, “The 'New' Federal Judicial Appointment Process: The First Ten Years” (2000)

38 Alta L Rev 616. 
"this person is qualified to be a judge" -- and since 2006, they cannot even say "well qualified". For yet another, the committees' solicitation of input through consultation is not the complete process but only part of it, given that the minister subsequently pursues a parallel set of inquiries in any event. Further, it is only a "personal undertaking" from a particular minister fifteen years ago, and not a formal requirement, that the minister's ultimate choice will be constrained by the list of approved candidates. Finally, the most recent set of changes to the structure of the committees was explicitly defended by the Prime Minister as a way of selecting judges more sympathetic to his government's policy emphasis of "cracking down on crime".

\section{SCREENING, RECOMMENDING, NOMINATING, AND SELECTING}

Who, in the end, actually selects judges in Canada? That is to say, what person or what committee of persons makes the final decision narrowing any list to the name of the single successful candidate? For all the provinces and for the federal government as well, the answer to that question is still: the minister (sometimes with the involvement of the premier/prime minister or the cabinet). Despite all the committees that have been created and all the hours of conscientious effort their members have invested, we are still, in Evans' phrase, in the age of the Power of One. ${ }^{18}$ The names and titles in Table 1 notwithstanding, the Quebec committees do not select, the New Brunswick committee does not appoint, and the Alberta committee does not nominate. Instead, what all these provincial and federal structures actually do is some mixture of screening and recommending, and these are lower order functions. Since these terms tend to be used casually and somewhat interchangeably, I will suggest a more rigorous vocabulary, as outlined in Table 4 . $^{19}$

Table 4: Clarifying Terms in the Appointment Process

\begin{tabular}{|l|l|}
\hline Function & Descriptor \\
\hline Initiation & Putting names "in play" for consideration for appointment. \\
\hline Screening & Ensuring names have critical credentials or qualifications. \\
\hline Recommending & Creating a "long short list" of potential appointees. \\
\hline Nominating & $\begin{array}{l}\text { Creating a short list, possibly ranked, from which final selection } \\
\text { is made. }\end{array}$ \\
\hline Selecting & Making the final choice of the single name to be appointed. \\
\hline Vetoing & Nullifying the act of selection, forcing an alternative choice. \\
\hline Appointing & Officially and legally vesting the person with the position. \\
\hline
\end{tabular}

17 Carissima Mathen, "Choices and Controversies: Judicial Appointments in Canada" (2008) 58 UNBLJ 53 at 61.

18 Evans, supra note 2.

19 Eva Liu \& Wai-lam Cheung, "The Process of Appointment of Judges in Hong Kong and Some Foreign Countries: Overall Comparison" (2001) online: Research \& Library Services Division, Legislative Council of the Hong Kong Special Administrative Region of the People's Republic of China 〈http://www.legco.gov.hk/yr00-01/english/library/erp01.pdf >. 
The process of initiation is now straightforward: candidates apply for judicial positions by filling out application forms and supplying references in much the same way as people seek employment in most other occupations. At one time, one patiently waited to be invited (the "judicial tap on the shoulder"), and some Canadian jurisdictions retain a vestigial language implying that some modestly wait to be nominated or proposed by someone else, but the core reality is that today one's name is put into play by the candidate's own action of formally and explicitly applying for the position.

Screening is the process of reviewing applications to ensure the presence of critically necessary credentials or qualifications -- at a minimum, membership in good standing in a law society with the required years of experience in practice (ten in most provinces, five in P.E.I. and New Brunswick, fifteen for Nova Scotia). This is built into the current practice (for example, there are more total applicants than candidates interviewed), but all the councils and committees do more than this.

Recommending is the process of applying more demanding criteria to a large initial set of names to narrow consideration to the more worthy applicants. Looking at the figures reported by the B.C. Judicial Council over the past decade, it would appear that about $40 \%$ of all applicants are approved for further consideration. This is a stronger role for an advisory committee, but (especially when the process is generating a multi-year pool from which appointments can be drawn) it still leaves the minister with considerable discretion.

Nominating is the process of generating a small short list, possibly but not necessarily ranked. Only two provinces allow their advisory committees to nominate: the Manitoba JNC must submit not less than three and not more than six names; and the Ontario JAAC provides a short list of "at least two" names (although in recent years the average is four). Screening, recommending and nominating are notions located along a continuum rather than three hard points with crisp boundaries, but they usefully distinguish between minimal, moderate, and significant constriction of ministerial choice. Nominating is only really possible for a reactive committee -- one that deals with a set of applications targeted on a single identifiable judicial vacancy -- and not for the more common anticipatory role.

Selecting is the process of identifying the single individual to be appointed to a judicial vacancy, narrowing the screened or recommended or nominated list to this logical culmination of the process. In Canada, this decision making power, the most critical point along the appointment track, is always assigned to the minister.

Vetoing $^{20}$ is the process of passing judgment on the individual who has been selected, with the logical (but not necessarily particularly likely) possibility that the consideration will be negative and the individual will be rejected. At one time, the Judicial Councils of both Ontario and Saskatchewan received the single name of the person that the minister wished to appoint to a judicial position, with the responsibility of considering the person's credentials and then reporting back to the minister; New Brunswick names an ad hoc interview committee to exercise this same function for ministerial selectees.

Appointing is the formal act of putting the individual in the position. In Canada, this is always an action of the Crown (the governor-in-council for federal

20 Ibid. Liu and Cheung use the more positive but less informative label endorsing. 
appointees, the lieutenant governor-in-council for provincial appointees), but this has become a formality, given that the possibility of not appointing has for all practical purposes vanished.

It is not difficult to locate the various provincial and federal bodies within this conceptual framework: almost all recommend candidates for appointment, the Ontario JAAC and the Manitoba JNC nominate, and the New Brunswick interview committee reviews ministerial nominees for possible veto. Actually selecting (choosing the "winner") is the prerogative of the minister. In Alberta, for example, should a judicial position become vacant today, the minister has an existing pool of just under one hundred names from which to make a choice; in Saskatchewan, the same pool includes about three dozen names. Even in the provinces where the committee nominates a short-list, the minister retains the right to reject the list and request a new one, or to ask that it be enlarged to include more names, or to ignore the ranking within a ranked short-list.

This being the case, the opposition and the media in Quebec were quite right to be looking straight past that province's judicial selection committee procedure to target the justice minister and the premier as being at the centre of the alleged judicial appointment scandal in that province. Despite the establishment of this pan-Canadian string of councils and committees, in no province does anybody other than a minister decide which specific individual becomes a judge.

\section{THE SIX CHALLENGES OF JUDICIAL APPOINTMENT REFORM}

Kate Malleson, in her influential book The New Judiciary, sees the basic focus of contemporary judicial system reform as finding an appropriate response to "increasing pressure for greater accountability and openness." ${ }^{21}$ It is in these terms that one can identify what I will describe as the six major challenges to judicial appointment reform in Canada. I take it that the lay members within the advisory committees embody this new principle of accountability (just as the judicial members embody judicial independence, and the lawyer members embody professional values), and this lay involvement creates a triple challenge that, in most jurisdictions, remains largely unmet. Openness, (or "transparency") is the fourth challenge; and secure institutional foundations for the operations of the committees is the prerequisite fifth.

\section{A. First: The Challenge of Autonomous Lay Membership}

The first question about the lay members is how they came to be on the committee in the first place. The judges serve ex officio; the lawyers have a connection with a professional organization; but the lay members typically were selected by the minister.

To be sure, to see the biographies of these individuals (in those few provinces that provide the information) is to be impressed. Typically, they have considerable professional and business experience; they have served in regional, provincial and national work-related organizations; and they have served on public and public interest organizations as well. But the question remains -- why this person, and not one of the many others with comparable credentials? The answer always is:

21 Kate Malleson, The New Judiciary: The Effects of Expansion and Activism. (Aldershot, UK:

Ashgate/Dartmouth, 1999) at 1 [New Judiciary]. 
because the minister so decided, for undisclosed reasons based on unpublished criteria, such that the choice may be (impossible to disprove once the question is raised) connected to a partisan or ideological or personal agenda. As has pithily been observed, the great challenge of judicial selection design is "who picks the pickers." ${ }^{22}$

Kate Malleson prefers that lay members serve terms that are both long and non-renewable $\square$ long so that they can establish their presence and their role within the committee, and non-renewable to preclude any suggestion that toward the end of that term they might play to the reappointing authority. ${ }^{23}$ But, worldwide, the tendency is very much the opposite: short, renewable terms, exacerbating these concerns rather than mitigating them. This is also very much true of the Canadian committees, as shown in Table 5. The normal term is three years (or shorter); and where the information is available, the terms are renewable, usually without any stated limit.

\section{Table 5: Lay Members on Appointment Advisory Committees}

\begin{tabular}{|l|l|l|l|l|}
\hline & Type & Number & Term & Renewable? \\
\hline $\begin{array}{l}\text { British } \\
\text { Columbia }\end{array}$ & Judicial Council & 2 & 3 years & Yes \\
\hline Alberta (1) & Judicial Council & 2 & Not stated & $?$ \\
\hline Saskatchewan & Judicial Council & 2 & 3 years & Yes (once) \\
\hline Newfoundland & Judicial Council & 2 & 3 years & Yes \\
\hline Alberta (2) & Standing Committee & $4-5$ & Not stated & $?$ \\
\hline Ontario & Standing Committee & 7 & 3 years & Yes \\
\hline Nova Scotia & Standing Committee & $2-4$ & "1 or 2" years & Yes \\
\hline Manitoba & Ad hoc committee & 3 & Not applicable & Not applicable \\
\hline Quebec & Ad hoc committee & 1 & Not applicable & Not applicable \\
\hline P.E.I. & Ad hoc committee & 2 & Not applicable & Not applicable \\
\hline New Brunswick & Other & 2 & Not stated & $?$ \\
\hline
\end{tabular}

Recent British reforms have shown a way out of this box. For both the English Judicial Selection Commission and the Scottish Judicial Appointments Board, applications are invited from the public and a neutral selection committee is used to screen those applications, short-list, interview and select the members. ${ }^{24}$ The normal term is five years in England, four years in Scotland, and reappointment (for a single additional term) requires reconsideration by that same selection committee. An additional benefit is the fact that the call for applicants will have transparently publicized the expectations of the position for the information of potential commission members and general public alike. This is something of an elaborate detour on the road to staffing the committee, but it directly enhances the role of the committee in a way that the shadow of fully discretionary ministerial choice does not.

22 Shira A Goodman \& Lynn A Marks, "A View from the Ground: A Reform Group's Perspective on the Ongoing Effort to Achieve Merit Selection of Judges" 34 (2007) Fordham Urb LJ 425 at 437.

23 Malleson, New Judiciary, supra note 21 at 134.

24 For English appointments see ibid; for Scottish appointments see Alan Paterson, "The Scottish Judicial Appointments Board: New Wine in Old Bottles?" in Malleson \& Russell, supra note 5 


\section{B. Second: The Challenge of a Meaningful Lay Role}

A question arises of what it is that lay members, once appointed, are supposed to do. The problem here is the considerable mystique that has attached to the judicial role, such that the duties and requirements of the position are typically described in terms of "very generalised qualities" that are "inherently difficult to measure quantitatively." $"$ For example: the mandate of the Manitoba committee is to assess "the professional excellence, community awareness and personal suitability" "intellectual and judgmental ability" ${ }^{27}$ to that list. It is hard to see how much a lay member could contribute to this assessment. Rickard (writing of the South African Judicial Selection Commission) likes the idea of lay members, but defends them as being like the little boy who sees that the emperor has no clothes. ${ }^{28}$ Like many metaphors, this may cut rather deeper than he intended, portraying the lay members as children among the legal professional adults. The more that judicial potential is assessed in terms of personal qualities that display themselves in particular settings, the greater the disadvantage of the lay members. ${ }^{29}$ Consequently, as Bowal suggests, the lay perspective cannot be anything more than an "overall impressionistic one.",

The solution to mystification is demystification. Rather than talking of the judicial role in vague and impressive generalities, familiar to some committee members but mysterious to others, it needs to be translated into a set of relevant criteria, each linked to demonstrated or potential skills and abilities which are in turn connected to potentially available empirical information. The English JAC is well on its way to filling out the implicit middle step by increasingly requiring candidates to sit specifically designed qualifying tests targeted on the relevant judicial post. Matching credentials and demonstrated experience to a specific set of criteria is something many laypeople can do well because it is a normal part of their work experience (and such experience should be an element of the lay member selection process); they cannot challenge a judicial member's evaluation of whether a candidate would make a "great" judge, but they can definitely join the conversation as to whether the candidate's background meets such requirements as a demonstrated interest in law reform or alternative dispute resolution or the social context of the cases that typically go to court. (All three examples are drawn from the published criteria for judicial appointment in Ontario, British Columbia and Nova Scotia). This argues strongly for a reactive rather than an anticipatory procedure, so as to permit the establishment of the clearest set of relevant criteria; this provides a useful focus for the lay members,

\footnotetext{
25 Malleson, New Judiciary supra note 21 at 96.

26 Wording was taken from taken from the 2010 on-line announcement of a vacancy for a provincial judgeship in Dauphin Manitoba [no longer accessible].

27 Wording was taken from the 2010 on-line application form for the vacancy for a provincial judgeship in P.E.I. On file with author.

28 Carmel Rickard "The South African Judicial Selection Committee" (Paper delivered at the

Conference on Judicial Reform: Function, Appointment and Structure, Centre for Public Law, University of Cambridge, 20013) at 5, online: University of Cambridge <http://www.law.cam.ac.uk/faculty-resources/conference-papers/17>.

$29 \quad$ Ibid at 4

30 Bowal, supra note 14 at 6.
} 
and appropriately accommodates the expanding diversity of provincial judicial responsibilities and specializations.

Several jurisdictions (most notably Ontario, British Columbia, Nova Scotia and Alberta) have developed extended categorized statements of judicial appointment criteria; and Paterson suggests that the implication of this development is that the application form, and the referees' forms as well, become increasingly "formidable documents" focused on specific skills and competencies. ${ }^{31}$ The Scottish JAB has taken the further, and highly controversial, step of prohibiting not only the "secret soundings" whereby judicial members collect confidential feedback from their colleagues, but also personal information about specific candidates held by either legal or judicial members. ${ }^{32}$ Such information not only gives unfair advantage to certain types of candidate but also renders participation by the lay members, who can make no similar "soundings", more problematic.

\section{Third: The Challenge of Effective Lay Participation}

The third challenge is creating the circumstances in which lay members actually participate in the conversation (once the second challenge has been met, and there is a conversation in which they could reasonably and credibly take part). This is a real challenge, because the judicial members in particular are rather intimidating senior professionals, such that the lay members may "defer inappropriately to the legal insiders, particularly senior judges." ${ }^{, 33}$ Interviewed in the early 1980s, many legal professionals on Canadian provincial judicial councils "wished that the lay members would speak up more" ${ }^{, 34}$; and Malleson speaks of many lawyers and judges on American state merit nominating committees who "regard the lay members as something of an irritant."

Table 6: Membership of Appointment Advisory Committees

\begin{tabular}{|l|l|l|l|l|}
\hline Province & Judges & Lawyers & Other & Total \\
\hline British Columbia & 3 & 3 & 3 & 9 \\
\hline Alberta (1) & 3 & 1 & 2 & 6 \\
\hline Alberta (2) & 1 & 6 & 4 & 11 \\
\hline Saskatchewan & 5 & 1 & 2 & 8 \\
\hline Manitoba & 2 & 2 & 3 & 7 \\
\hline Ontario & 3 & 3 & 7 & 13 \\
\hline Quebec & 1 & 1 & 1 & 3 \\
\hline New Brunswick & 3 & 4 & 2 & 9 \\
\hline Nova Scotia & 2 & 2 & 4 & 8 \\
\hline P.E.I. & 1 & 2 & 2 & 5 \\
\hline Newfoundland & 2 & 1 & 2 & 5 \\
\hline Composite Total & 27 & 29 & 35 & 91 \\
\hline
\end{tabular}

Paterson, supra note 24 at 23.

Ibid at 21.

Malleson, New Judiciary, supra note 21 at 96.

McCormick, supra note 4 at 181

Malleson, New Judiciary, supra note 21 at 134. 
The essential factor in establishing a participating lay component is the presence of a critical mass of lay members within the committee. This "critical mass" refers in part to the absolute number of lay members present, and in part to the proportion of the total committee that they comprise; Malleson's preference is for large committees with either more members than, or the same number as, the two other elements combined. ${ }^{36}$ This can be reinforced by providing for a lay chair of the committee, as is the case for the Ontario JAAC (and, abroad, for both the English JAC and the Scottish JAB); in Canada, however, the chair is almost always either a Chief Judge or Justice, or someone selected by the Minister.

\section{Table 7: Chairmanship of Appointment Advisory Committees}

\begin{tabular}{|l|l|l|}
\hline Province & Type & Chair \\
\hline British Columbia & Judicial Council & Chief Judge, ProvCt \\
\hline Alberta & Judicial Council & Chosen by Council \\
\hline Saskatchewan & Judicial Council & Chief Justice, Province \\
\hline Newfoundland & Judicial Council & Chief Judge, ProvCt \\
\hline Alberta & Standing Committee & Named by minister \\
\hline Ontario & Standing Committee & Named by minister \\
\hline Nova Scotia & Standing Committee & Chosen by committee \\
\hline Manitoba & Ad hoc committee & Chief Judge, ProvCt \\
\hline Quebec & Ad hoc committee & Named by minister \\
\hline P.E.I. & Ad hoc committee & Chief Judge, ProvCt \\
\hline New Brunswick & other & [not applicable] \\
\hline
\end{tabular}

It also critically important that the committee develop a collective identity that transcends the backgrounds or implicit commitments of the various members, such that they pull together to create consistency in their deliberations and a united front against challenges. ${ }^{37}$ The lay members, as the more marginal and vulnerable elements of the committee, have the greatest need for this collective solidarity to anchor their active and effective participation. This argues strongly for a standing, rather than an ad hoc, committee, as well as one that has responsibilities other than simply meeting to interview and nominate (such as the public relations responsibilities of Ontario's JAAC).

But the unavoidable problem is that even if the committee is so structured that the numbers seem to favour the lay members, they continue to work under a disadvantage. The lawyer members have the advantage of common professional values and shared experiences such that they are more likely to perform cooperatively; except in the large provinces, they are likely to know each other already as well (and possibly also to know many of the candidates for appointment). The same is true, even more so, of the judges. But the more diverse the backgrounds that have been used to generate the lay members, the less likely they are to begin with any comparable cohesiveness, or to have any real opportunity to develop it through the committee's sporadic and occasional meetings.

$36 \quad$ Ibid at 48.

37 Kate Malleson, “Assessing the Performance of the Judicial Service Commission” (1999) 116 South African Law Review 36 at 38. 


\section{Fourth: The Challenge of Transparency}

Malleson suggests that the first criterion for assessing the openness of an appointment system is "the extent to which the mechanics of the process and the selection criteria which are adopted are made known to the public." ${ }^{38}$ In the twenty-first century, the normal mechanism for this availability is the internet, but to date the performance of Canadian jurisdictions is most unimpressive. No appointments advisory committee has its own freestanding website, and only two even have their own webpage on the provincial court website those being (Ontario and British Columbia). These are the two committees that produce regular reports (every year for Ontario, every two or three years for B.C.), ${ }^{39}$ easily accessed for the past decade or more; these are also the only two committees which provide names and biographical information about their own current membership. Ontario is the only province where there is any attempt to educate a broader public about the process; its members make themselves available to speak to a variety of groups about the appointment process.

No other province offers remotely comparable information. Specifically:

- The Saskatchewan Judicial Council has a single page on the Saskatchewan Provincial Court website, with links to the relevant statute (the Provincial Court Act) and to a "judicial candidate information form." However, the Council being a multi-purpose body, there is considerably more information on the webpage about the complaint process for provincial court judges; and there is no an annual report, or any description of past activities.

- The Nova Scotia committee has no website, and no webpage on any other government or court website. The Nova Scotia Department of Justice Court Services website has a cryptic single sentence entry with links to two pdf documents, one of which is the "appointment guidelines" (a five-page document describing the procedure and criteria for appointment) and the other a "judicial application form."

- The Alberta Judicial Council is described in a four-line entry on the Justice Department website, with a link to the relevant statute; there is no further information about the current membership of the council or its procedures. The more recently created Provincial Court Nominating Committee has only a simple two-line description with no links. Neither the Judicial Council nor the Nominating Committee produce reports of any kind.

- The Cour du Québec website provides a link to the Quebec government regulation regarding the selection committees, but without any further description of structure or 
procedure. For this information, one must go to the Barreau du Québec webpage, which provides a single page with a description of the process and a short statement of the relevant criteria.

- The Manitoba Provincial Court website provides a singlesentence description of the membership of the nominating committee, but the only link is to a Judicial Candidate Information Form. Curiously, the description does not even mention that the committee has a statutory foundation (in the Provincial Court Act), let alone provide a link to it. The Provincial Court issues annual reports, but they make no mention of the nominating committee or of the appointment process.

- For the Newfoundland Judicial Council, there is no website and no webpage on any other government or court website. A search engine takes you to an application form put online just last year, but the links on that form are no longer valid.

- The New Brunswick process is briefly described in a single sentence on the New Brunswick Provincial Court website (as a screening process conducted by a committee), but there is no further information about either this "committee" or the appointment process. Press releases for appointments in the province do not mention the advisors' group or describe the process.

- The Prince Edward Island nominating committee is not mentioned on any provincial government or court website; a search engine will take you to a press release from 2007, briefly describing the committee and its cryptic evaluatory criteria.

This does not add up to very much; with the very important exceptions of Ontario and British Columbia, the average citizen is still very much in the "just trust us" era when it comes to the judicial appointment process. In most provinces, little information is available about the process, or about what advisory councils or committees are involved, or about what specific criteria are being applied. $^{40}$ Even the press releases for new provincial court appointments do not, in many provinces, include any reference to the screening committees or the advisory process, a surprising oversight in light of the "transparency" rhetoric that so often accompanies the establishment of the committees.

\section{E. Fifth: The Challenge of Institutional Independence}

The Judicial Councils that figured prominently in the first fifteen years were all statutory bodies with strong ex officio membership -- the principle of judicial

40 The list above provides some indication of how fragmentary and scattered the documentation for these committees is; for a fuller explanation and identification of sources, please see the more substantial paper from which this paper is derived: Peter McCormick, "Selecting Trial Court Judges: A Comparison of Contemporary Practices" prepared for the Commission of Inquiry into the Appointment Process for Judges in Quebec (Bastarache Commission), October 2010; online: Government of Quebec <http://www.cepnj.gouv.qc.ca/études-des-experts.html>. 
independence clearly requires this, as has been spelled out by the Supreme Court in a remarkable string of decisions. ${ }^{41}$ But the move from judicial councils to advisory committees has meant a significant weakening of this foundational base. Some advisory committees (those of Quebec, Manitoba and Ontario) have been established by statute, with specific composition and powers (although the ad hoc nature of the Quebec and Manitoba committees precludes any firm institutional evolution from this foundation, since there is no ongoing institution to evolve). But other jurisdictions have proceeded in much more casual ways, as Vaillancourt has noted. ${ }^{42}$ Nova Scotia's committee exists by order of the Executive Council; Prince Edward Island's was simply proclaimed by the minister, as was Alberta's; and if New Brunswick's advisory group has any clear foundation at all, I have been unable to find it. The federal judicial advisory committees are also a case in point -- established by ministerial fiat, successively modified several times (and never in a way that diminished the Minister's influence) through similar means, without even any assurance other than the "personal undertaking" of a former Minister that candidates it declines to recommend will not be appointed anyway.

Even the more clearly established committees have suffered some "push back" from their own governments. The Ontario Judicial Appointments Advisory Committee, arguably the poster child of judicial appointment reform and in foreign commentary, is an example. Its annual reports from the turn of the century reveal a bruising confrontation with the Harris government; for several years in a row it juxtaposes a "The Minister has publicly said" emphasis on a particular kind of experience -- identified more specifically as prosecutorial trial experience ${ }^{43}--$ to its own "but the committee continues to believe" defence of its broader range of criteria. To be sure, one can see this as a happy ending -- the JAAC stood firm against the minister's direct pressure and defended its own full set of criteria. But the number of names submitted each year has for a decade been double the "at least two" in the legislation (119 appointments from 478 recommendations), ${ }^{44}$ the precedent for over-riding the ranking within the short list is clear, and the transparent pleasure in one report at the appointment of one of "their" kind of recommendees surely implies that most of the dozen judges appointed every year were not. If this has been the recent experience of one of the statutory bodies, it is naive not to think of the more casual status of the others as providing a weaker base from which to develop an independent stance that might not mesh with the minister's personal preferences.

\section{CONCLUSION}

On the one hand: Canadian politicians at the federal and provincial level alike are somewhat more constrained in the selection of judges than they were fifty years ago, with independent professional bodies formally interposed at some stage

$41 \quad R v$ Valente, supra note 8 was the first case in this sequence, but over the next fifteen years the Court handed down about two dozen decisions further exploring and refining the principle and the requirements of judicial independence. See McCormick, supra note 8.

42 Vaillancourt, supra note 12 at 271

43 Ian Greene, "Democracy, Judicial Independence and Judicial Selection for Federally Appointed Judges" 58 (2008) UNBLJ 105 at 109.

44 Ontario Judicial Appointments Advisory Committee, supra note 39 
of the consideration process. On the other hand: politicians still have the final say in who becomes a judge, exercising a considerable degree of closeted discretion in the making of this choice. To explain this apparent paradox, I think we have to consider more closely just what it was that current appointment procedures were intended to do, and I will do so by presenting four distinct (albeit somewhat overlapping) possibilities.

The first purpose that might be served by judicial appointment committees is legitimacy enhancement. No matter what the structure of the committee, or the method of the selection of its members, or the details of the procedures through which it operates, the interposition of an arm's-length committee between the naked discretion of the minister and the selection of judges reduces the partisan dimensions of the process and enhances the neutrality and therefore the credibility of the court to which the judges are appointed. The participation of judicial members, legal professional members, and lay members who represent the public provides, if you will, a triple dose of this legitimacy; it brings together in one process the three relevant communities, and simultaneously downplays the partisan political overtones that have historically tended to cloud even objectively good appointments. From my perspective, it might be arms-length for a very short arm, but "better than ever before" and "no worse than the neighbours" can carry the day if nobody really presses the point.

The second purpose that might be served by these committees is quality control. This need was particularly acute when the provincial courts were first created to replace the magistrates courts that preceded them. Henceforth, these judges were to exercise more extensive powers within a framework including stricter protections for judicial independence, and the credibility of this new exercise depended very much on persuading the general public and the legal professionals that the new judges were up to this challenge. A strict screening process working at arms' length from government was therefore invaluable -- it ensured not only a minimum level of formal credentials (although this too was part of what Peter Russell has called "the judicialization of the magistracy" a review of character and prior performance that raised the bar significantly. Less than half of the applicants for judicial appointment meet this higher standard, which clearly makes the point; we can also assume an element of deterrence for minimally qualified candidates who might otherwise have put their names forward.

The third purpose that might be served is merit selection, a process designed to put the single most qualified and suitable candidate into any specific judicial position. The occasional rhetorical flourish aside, this was never part of the project in Canada. It is forestalled by the fact that so many of the judicial appointment committees in Canada are anticipatory rather than reactive -approving a pool of candidates in advance on general grounds rather than designating this person for this specific set of judicial responsibilities -- and by the fact that most committees (but not all of them) can at best distinguish between "qualified" and "well-qualified" candidates rather than putting forward a short-list (let alone a ranked one). To be sure, the distinction between quality control and merit selection is one of degree rather than one of kind -- ratchet the quality

45 Peter Russell, The Judiciary in Canada: The Third Branch of Government (Toronto: McGraw-

Hill Ryerson, 1987) at 208 
control level up high enough, and one has merit selection -- but since this ratcheting-up has not happened in Canada, it remains a distinction worth making.

A fourth purpose that might be served is political insulation, which is to say genuine insulation, and not the "arms-length for very short arms" mentioned earlier. This would require an appointment procedure allowing as little direct political influence (by politician or political party officer or political office-holder) as possible. Historically, we would have understood this as the prevention of patronage, by which judicial appointments were rewards for past political performance, or linked to political connections and alliances, such that people lacking such performance or connections were largely precluded or at least seriously disadvantaged. A more sordid variant would involve corruption, with judicial appointments linked to direct pay-offs of various kinds, such that specific individuals or interests can direct the appointment of judgments, presumably for softer treatment in future. In a different direction, we might worry that political influence would reveal itself in the ideological stacking of the courts, with the appointing officials promoting specific values or priorities or ideologies through judicial selection. These three alternate descriptions cover a real range -- the first was once accepted but is now widely disapproved of; the second is clearly inappropriate if not illegal; and the third is sometimes defended as a way of keeping courts and judges responsive to electorally-expressed shifts in popular opinions and values -- but all three are potentially at play when partisan officeholders retain a range of discretionary choice. Nothing in the procedures set up in Canada (except perhaps the short-lists in Manitoba and Ontario) confronts this, beyond the quality control guarantee that at least it will not generate less-thancompetent judges, which admittedly is not a small thing.

This being the case, the potential for scandals such as those alleged to have occurred in Quebec are simply built into the process. Given the considerable discretion enjoyed by political office-holders in making the final selection within a broad field of choice, and the constrained role to which all of the so-called "appointment" committees have been relegated, these could happen anywhere. Should this happen, attention will (as it was in Quebec) rightly be directed not at the committee, but at the politician or politicians who make the actual selection, at which point the closeted nature of this last stage of the process frustrates attempts to dispel the rumours with any finality. Should Canadians wish to see procedures that are transparently directed at merit appointments strictly insulated from political influence, the minor tweaking of current structures will not be enough; for more modest purposes and expectations, the existing diversity of committee composition, structures and procedures with their rather modest constraints on choices made by partisan officials will perhaps continue to serve nicely. 